\title{
Phenol as Waste Water Constituent in Petroleum Refining
}

\author{
Raphael Ngochindo \\ Department of Pure and Industrial Chemistry \\ University of Port Harcourt, Choba, P. M. B. 5323, Port Harcourt, Nigeria
}

\begin{abstract}
Phenol appears ubiquitous in the refining of petroleum and constitutes a hazardous component of refinery effluents. The level of this chemical in refinery waste water requires constant monitoring in order to avert environmental contamination and possible litigation. The available method for estimation of the amount of phenol in refinery wastes at the Port Harcourt Refinery is a calorimetric procedure that employs an ultra violet spectrophotometer. In the event of a breakdown of the ultra violet spectrophotometer, an alternative procedure for phenol estimation becomes essential. To meet this demand, a novel method was recently developed for the estimation of phenol in refinery waste water by a gravimetric procedure. The procedure as an analytical tool is not known to have been previously reported in the literature. The reaction is here also being proposed as a possible method for the removal of phenol from refinery effluents.
\end{abstract}

Keywords: Phenol, petroleum refining, gravimetric analysis, colorimetric analysis.

\section{Introduction}

Petroleum processing is a complex endeavour worldwide. Nigeria, with four refineries in Eleme (two), Warri and Kaduna, has to contend with the environmental impact of its refining processes, one of which is the generation of phenol. The crude oil refined at the Port Harcourt Refinery Company (PHRC) is Bonny Light Crude and is among the best in the world by virtue of its components. Phenol is one of the organics containing nitrogen, sulphur and oxygen (the so called NSOs) found in the crude that is essentially composed of saturated and unsaturated hydrocarbons, including aromatics. It has been observed that the level of phenol is higher at PHRC when the Fluid Catalytic Cracker Unit is on stream.

Phenol is a transparent crystalline solid with melting point of $40.5^{\circ} \mathrm{C}$ and a boiling point of $181.7^{\circ} \mathrm{C}$. With a pKa of 9.95 in water, it is weakly acidic. The chemical is corrosive to the eyes, skin and respiratory tract [1]. Prolonged skin contact with phenol may cause dermatitis (skin inflammation), or even second and third-degree burns [2]. Inhalation of phenol vapour may cause lung oedema [1] (a build-up of excess serous fluid between tissue cells). The substance may cause harmful effects on the central nervous system and heart, resulting in dysrhythmia (irregular heart or brain rhythm), seizures, and coma [3]. Long-term or repeated exposure of the substance may have harmful effects on the liver and kidneys [4]. Phenol at a level of $9 \mathrm{mg} / \mathrm{l}$ in the blood is reported to cause death [5].

Phenol is very toxic to fish and has a nearly unique quality of tainting the taste of fish if present in marine environments at $0.1-1.0 \mathrm{ppm}$ [6]. The chemical is most injurious at $2.9 \mathrm{mg} / \mathrm{l}$ for aquatic ecosystem, with phytoplankton population reduction even in the concentration $1.3 \mathrm{mg} / \mathrm{l}[7]$.

Determination of phenol in PHRC is usually by ultra violet (UV) spectrophotometric analysis (colorimetric procedure). Faced with a faulty ultra violet (uv) spectrophotometer in the Quality Control Laboratory of PHRC, an alternative method of analysis of phenol was sought. This led to a gravimetric method, here referred to as the Ngochindo Procedure. In this method, the amount of phenol in the effluent is determined by its precipitation with bromine and the resulting 2,4,6tribromophenol (TBP) weighed to obtain the equivalent amount of phenol. In addition to the reaction of bromine with phenol as an analytical procedure as described in this paper, it is here also being proposed that the reaction can constitute a method for the removal of phenol from effluents in the refinery.

\section{Available Methods of Removal}

Several methods have been reported in the literature for the treatment of phenol in refinery effluent, some of which are briefly described below. 


\section{1. Polymerisation}

Phenol has been removed by its polymerisation in the presence of an enzyme: horseradish peroxidase (HRP) [8]. This involves the use of hydrogen peroxide and peroxidase enzyme. The enzyme is oxidised by hydrogen peroxide to an active intermediate enzymatic form which accepts an aromatic compound into its active site and carries out its oxidation. A free radical is produced and released into solution, leaving the enzyme in the compound state that can oxidise a second aromatic molecule and consequently release another free radical, returning the enzyme to its native state and thus completing the cycle. The radicals formed diffuse from the enzyme into the solution and react to form water-insoluble polymeric aromatic products which can be removed by liquid/solid separation. Phenol conversion by this method is reported to be greater than $90 \%$.

\section{2. Electro Coagulation}

Electrochemical removal of phenol has been achieved by coagulation of phenol using horizontal aluminium screens as electrodes [9]. Removal of up to 97\% was achieved after 2 hours in a solution at $\mathrm{pH} 7$. The rate of electro coagulation is reported to increase with decreasing phenol concentration. The method works best with phenol concentration not exceeding $30 \mathrm{mg} / \mathrm{l}$. Other researchers that used iron electrodes [10] employed a current density of $25 \mathrm{~mA} / \mathrm{cm}^{2}$ and at a solution $\mathrm{pH}$ of 7.

\section{3. Extraction.}

Simulated phenol removal using waste water from sebacic acid (decanedioic acid) has been reported [11]. The solvents employed were 1-hexanol, 1-heptanol and 1-octanol. The results showed that 1-octanol showed lesser phenol extraction ability compared with the other two.

\section{4. Photodecomposition}

This has been carried out in near-UV-irradiated aqueous $\mathrm{TiO}_{2}$ suspensions in which the effects of charge-trapping species on the kinetics of phenol decomposition was studied [12]. The heterogeneous degradation conditions for phenol appeared to have followed a zero-order kinetics up to $70 \%$ conversion. In the presence of silver ions, the phototransformation of phenol proceeds via direct electron transfer, without dissolved oxygen nor its reduced forms playing a significant role in the degradation mechanism. Photocatalytic degradation of phenol in the presence of UV irradiated $\mathrm{TiO}_{2}$ catalyst and $\mathrm{H}_{2} \mathrm{O}_{2}$ has been shown to be an effective method of phenol removal [13].

\section{5. Biological Methods}

Bioreactors have been applied successfully for the degradation of phenol. High concentrations of phenol up to $420 \mathrm{mg} / \mathrm{l}$ have been removed by biological and enzymatic treatment under aerobic biological conditions [14]. The method is preceded or followed by enzymatic treatment, with tyrosinase as enzyme. Enzymatic polishing of biotreated effluent has been reported to remove up to $75 \%$ of the remaining phenol in a four-hour reaction. Use of Pseudomonas putida in activated sludge by polymerase chain reaction has been reported [15]. It has been found that the bacteria can utilize 500-600 mg/l phenol completely after 48 hours incubation. Phenol degradation up to $700 \mathrm{mg} / \mathrm{l}$ has also been reported [16].

\section{6. Oxidation with Fenton's Reagent}

Fenton's reagent is a solution of $\mathrm{H}_{2} \mathrm{O}_{2}$ with ferrous ions (usually a solution of $\mathrm{FeSO}_{4}$ ) as catalyst and is used at $\mathrm{pH}$ 3-5 in the rapid and exothermic oxidation of organic compounds. It involves the generation of hydroxyl radicals in the mechanism. The process has been applied to waste water treatment involving phenol [17].

\section{7. Electro-Fenton Method}

The electrolytic method, also known as the EF-Fere method, uses $\mathrm{H}_{2} \mathrm{O}_{2}$ and electrogenerated ferrous ions [18]. Best results were obtained with continuous addition of $\mathrm{H}_{2} \mathrm{O}_{2}$, initial ferric ions concentration of $800 \mathrm{mg} / \mathrm{l}$, electric current of 1.0 A, use of $\mathrm{SnO}_{2}$ film anode and UV irradiation.

\section{8. Adsorption and lon Exchange}

Liquid-phase adsorption of phenol from water by silica gel, activated alumina and activated carbon has been studied [19]. Reports have also been made of the use of polymeric resins, sawdust, polymerised sawdust, sawdust carbon and 
hyacinth as adsorbents. The sources of activated carbon include oil palm shells and rice husks. Particle size of 0.420 was recommended. Phenol removal was $88-95 \%$. The advantage of this method is that it utilizes agricultural wastes.

\section{9. Membrane Based Separation}

This is based on ionic and covalent cross-linked ethylene-methacrylic acid copolymers [20]. The phenol/water ratio in the feed studied was 3-8 weight per cent with non-modified as well as cross-linked ethylene-methacrylic acid (E-MAA) copolymers with different amounts of methacrylic acid.

\section{10. Reuse of Waste Water for Cooling}

Waste water containing up to $100 \mathrm{ppm}$ of phenol has been reduced to a level of about $10 \mathrm{ppm}$ by the reuse of the waste water [21]. The general practice is that water is used to lower the temperature of the coke and coking drum prior to removing the coke therefrom. The water utilized to cool the coking drum initially vaporizes along with oil vapours and is passed to a blow-down drum. The blow-down drum may also receive steam from exhaust pumps and other utilities in the coking operation. After the bed of coke in the coking drum has cooled to below $100{ }^{\circ} \mathrm{C}$, the cooling water no longer vaporizes and the interstices become filled with water. This water is then withdrawn from the coking drum and can be reused in either the cooling step or the subsequent hydraulic cutting step.

\section{11. Catalytic Wet Air Oxidation}

Extensive research has been conducted on liquid phase oxidation of phenols in industrial waste water using an adsorbentcatalyst matrix [22]. Oxidation is achieved with $1 \mathrm{vol} \% \mathrm{H}_{2} \mathrm{O}_{2}$ as radical initiator in spent catalyst from the Fluid Catalytic Cracking Unit, impregnated with $0.97 \% \mathrm{Fe}_{2} \mathrm{O}_{3}$. Reaction occurred at a pressure of $0.4 \mathrm{~cm} \mathrm{Hg}$ at $50{ }^{\circ} \mathrm{C}$. The procedure led to about $100 \%$ mineralization when tested with refinery stripped sour water.

\section{12. Enzyme-Catalysed Treatment}

Similar to the procedure reported in Section 2.5, this procedure uses Arthromyces ramosus peroxidase (ARP) to treat petroleum refining waste water containing $2 \mathrm{mM}(188 \mathrm{mg} / \mathrm{l})$ phenol in a batch and continuous-flow system [23]. The latter consisted of a plug-flow reactor (PFR) where the reaction took place between phenol and hydrogen peroxide catalysed by the enzyme in the presence of polyethylene glycol (PEG). A flocculation tank followed the PFR where alum and sodium hydroxide were added and then the polymers formed were settled in a sedimentation tank and removed from the system. Most (95 to 99\%) of the phenol was removed by the same dose of ARP required for the treatment of synthetic waste water containing an equal amount of phenol. Polyethylene glycol, as an additive, reduced enzyme inactivation and consequently reduced the enzyme dose and the cost of the treatment process. Step feeding of hydrogen peroxide was not effective in reducing the enzyme requirement. A significant removal of chemical oxygen demand was achieved when using PEG to reduce the enzyme dose.

\section{13. Chemical Treatment at PHRC}

Phenol is the third major component of sour water from the process plants, like hydrogen sulphide and ammonia [24]. The chemical procedure employed at the Refinery for the removal of phenol from waste water is the use of hydrogen peroxide. The use of Biodisks appears inefficient, but is also in use.

\section{Conventional Phenol Analysis}

Presently, the colorimetric analysis of phenol at the Refinery is carried out in two stages. The first stage involves addition of methyl red indicator (3 drops), sulphuric acid or phosphoric acid $(1 \mathrm{ml})$, copper sulphate $(1 \mathrm{ml})$ and distilled water $(15 \mathrm{ml})$ to the sample $(100 \mathrm{ml})$ in a $250 \mathrm{ml}$ conical flask, followed by distillation to collect $100 \mathrm{ml}$ of distillate into a measuring cylinder.

In the second stage, ammonium chloride buffer $(3 \mathrm{ml}), 4$-aminoantipyrine $(2 \mathrm{ml})$, and potassium ferricyanide $(2 \mathrm{ml})$ are added, each, to the distillate $(100 \mathrm{ml})$ and distilled water $(100 \mathrm{ml})$ as blank. The sample is scanned against the blank using $10 \mathrm{~mm}$ curvet cells at a wavelength of $510 \mathrm{~nm}$. This constitutes the colorimetric method of analysis. 


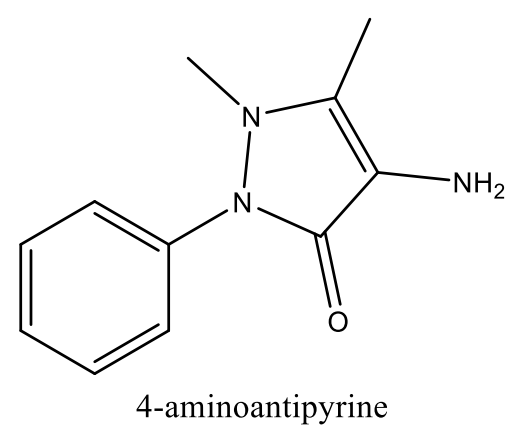

The conventional phenol analysis above is the only method of analysis at the Refinery. There is need for alternatives should the UV spectrophotometer develop faults, as is often observed.

\section{Discussion}

The gravimetric procedure involves the formation of 2,4,6-tribromophenol (TBP) from phenol, followed by determination of the phenol that gave the TBP. It is based on the fact that 1 mole of phenol gives 1 mole of TBP, by the equation:

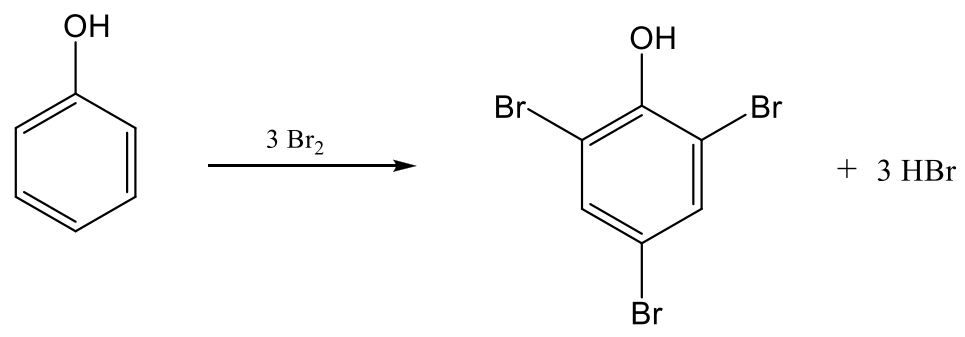

\section{1. Treatment of Results}

Let weight of waste water be $\quad \alpha \mathrm{g}$ weight of TBP formed be $\quad \beta \mathrm{g}$ weight of phenol in the sample be $\quad \gamma \mathrm{g}$ Then mole of TBP is $\frac{\beta}{330.8}$ and mole of phenol in the sample is $\frac{\gamma}{94.11}$ (Mol. weight of TBP is 330.8 while that of phenol is 94.11)

Since 1 mole of phenol gives 1 mole of TBP

$$
\begin{aligned}
& \text { Then } \begin{array}{l}
\frac{\gamma}{94.11}=\frac{\beta}{330.8} \\
\therefore \text { weight of phenol, }
\end{array} \quad \gamma=\frac{\beta}{330.8} \times 94.11 \\
& \begin{array}{l}
\text { and amount of } \\
\text { phenol in ppm, }
\end{array} \quad \delta=\frac{\gamma}{\alpha} \times 10^{6}
\end{aligned}
$$

\section{2. Confirmation of Analytical Method}

A confirmatory test for the gravimetric analysis of phenol was performed by the use of a standard solution of phenol. In the test, $53.8 \mathrm{mg}$ of phenol in $50 \mathrm{~g}$ of water solution was treated with bromine to obtain $185.1 \mathrm{mg}$ of 2,4,6-tribromophenol. This was calculated to be equivalent to $52.7 \mathrm{mg}$ of phenol. With a $1.1 \mathrm{mg}$ difference, which is equivalent to $2.0 \%$, the gravimetric method has been shown to be a good alternative to the spectrophotometric method for phenol analysis. 


\section{3. Application of Method}

Formation of 2,4,6-tribromophenol as a precipitate can be applied to the removal of phenol from waste water in the refinery process. This would require precipitation in a batch process.

2,4,6-Tribromophenol has a melting point of $95.5^{\circ} \mathrm{C}$, a boiling point of $244{ }^{\circ} \mathrm{C}$, a density of $2.55 \mathrm{~g} / \mathrm{cm}^{3}$ and solubility in water of $0.061 \mathrm{~g} / \mathrm{m}^{3}$. It is useful as a fungicide and as a wood preservative. It is an intermediate in the preparation of flame retardants. The precipitate is, therefore, of industrial importance. The procedure, therefore, constitutes the conversion of a hazardous chemical to a useful feedstock.

The importance of the Ngochindo Procedure is its adaptability to use in Modular Refineries presently being canvased for the oil-rich Niger Delta Region of Nigeria [25].

\section{Conclusion}

The management of the Port Harcourt Refinery appears burdened by the high cost of hydrogen peroxide which is imported through third parties into the country. The novel method here described for the quantitative analysis of phenol in refinery waste water appears to solve the problems encountered with the colorimetric method. The simplicity of the gravimetric method over the colorimetric method also suggests a better alternative procedure for the analysis of phenol in refinery waste water.

The reaction of phenol with bromine in the gravimetric procedure allows for the removal of phenol from refinery waste water. This now constitutes a novel method for the removal of phenol from the effluent in the refinery process.

\section{Acknowledgement}

Useful discussions with Messrs Isobo Tom-George, Harrison Wegwu, Charles Tamuno and Nyeh Omoiri in the Quality Control Laboratory of PHRC are appreciated. The author is grateful to the Nigerian National Petroleum Corporation (NNPC) for a Sabbatical Placement at PHRC, and the University of Port Harcourt for a Sabbatical Leave.

\section{References}

[1] S. Budavari, The Merck Index: An Encyclopedia of Chemical, Drugs, and Biologicals, ed. Whitehouse Station, NJ, 1996.

[2] T. M. Lin, S. S. Lee, C. S. Lai, S. D. Lin, Journal of the International Society for Burn Injuries, vol. 32, no. 4, pp. 517, 2006.

[3] M. A. Warner; J. V. Harper, Anesthesiology, vol. 62, no. 3, pp. 366, 1985.

[4] World Health Organization / International Labour Organization, International Chemical Safety Cards [online] Available: http://www.inchem.org/documents/icsc/icsc/eics0070.htm

[5] C. L. Winek, "Drug and Chemical Blood-Level Data," Allied Fischer Scientific, Pittsburgh, PA, 1985.

[6] Kirk-Othmer, Encyclopedia of Chemical Technology, 3rd ed., volumes 1-26, New York, NY, 1978-1984.

[7] N. C. Saha, F. Bhunia, A. Kaviraj, Bull. Environ. Contam. Toxicol., Springer-Verlag New York Inc., vol. 63, pp. 195, 1999.

[8] M. Stanisavljević and L. Neldic, Working and Living Environmental Protection, vol. 2, no. 4, pp. 345, 2004.

[9] O. Abdelwahab, N. K. Amin, E-S. Z. El-Ashtoukhy, J Hazardous Materials, vol. 163 no. 2-3, pp. 711, 2009.

[10] M. A. Zazouli, M. Taghavi, J. Water Resource and Protection, vol. 4, no. 980, 2012.

[11] N. N. Rao, J. R. Singh, R. Mishra, T. Nandi, J. Sc. and Ind. Res., vol. 68, no. 823, 2009.

[12] I. Ilisz, Z. László, A. Dombi, Applied Catalysis A: General, vol. 180, no.1-2, pp. 25, 1999.

[13] F. Akbal, A. N. Onar, Environ Monitoring and Assessment, vol. 83, no. 3, pp. 295, 2003.

[14] J. V. Bevilaqua, M. C. Cammarota, D. M. G. Freire, G. L. Sant’Anna Jr. Braz. J. Chem. Eng., vol. 19, no. 2, São Paulo, 2002.

[15] H. Movahedyan, H. Khorsandi, R. Salehi, M. Nikaeen, Iran. J. Environ. Health. Sci. Eng, vol. 6, no. 2, pp. $115,2009$.

[16] R. Pishgar, G. Najafpour, B. N. Neya, N. Mousavi, Z. Bakhshi, Iranica J. Energy and Environment, vol. 4, no. 348, 2011.

[17] S. Esplugas, J. Giménez, S. Contreras, E. Pascual, M. Rodríguez, Water Research, vol. 36, no. 4, pp. $1034,2002$.

[18] L. Jiang, X. Mao, Int. J. Electrochem. Sci., vol. 7, pp. 4078, 2012.

[19] N. Roostaei, F. H. Tezel, J Environ Manage., vol. 70, no. 2, pp. 157, 2004. 
[20] A. Mixa, C. Staud, Int. J. Chem. Eng., Article ID 319392, 2008.

[21] S. Gene, U. S. Patent 3284 337, 1961.

[22] A. K. Blankson, Ph.D Thesis, Kwame Nkrumah Univ. of Sc. and Tech., Ghana, 2012.

[23] M. S. Ibrahim, H. I. Ali, K. E. Taylor, N. Biswas, J. K. Bewtra, Water Environment Research, vol. 73, no. 2, pp. 165, 2001.

[24] I. Addington, C. Fitz, K. Lunsford, I. Lyddon, M. Siwek. (2015, November 25). [online] Available: http://www.bre.com/PDF/Sour-Water-Where-It-Comes-from-and-How-to-Handle-It.pdf

[25] U. Atumah. (2017, April 18). The Sun Newspaper. [online] Available: http://press.com.ng/niger-delta-and-modularrefineries/ 